\title{
Etika Profesi Konselor dalam Layanan Bimbingan Konseling Virtual
}

\author{
Raudatul Jannah*, Happy Karlina Marjo \\ Program Studi Magister Bimbingan dan Konseling, Fakultas Ilmu Pendidikan, \\ Universitas Negri Jakarta \\ *Corresponding Author. Email: RaudatulJannah_1108820004@mhs.unj.ac.id
}

\begin{abstract}
The purpose of this study was to describe the professional ethics of counselors in virtual counseling guidance services. The method used in this research is a literature study with a qualitative descriptive approach. The data sources come from document studies in the form of books and previous research from various references. Furthermore, the data analysis technique used is descriptive analysis. The results of this study indicate that online counseling takes the form of virtual counseling technology, namely, websites, telephone or cell phones, email, video conferencing, chat, instant messaging, computers, and other social networks. The ethical aspects that must be obeyed by online counselors are building good relationships on the Internet, confidentiality when conducting consultations, legal aspects of telecommunications via the Internet, and licensing. Therefore, online counselors need to be professional in conducting virtual counseling by considering ethics.
\end{abstract}

Abstrak: Tujuan penelitian ini adalah untuk mendeskripsikan etika profesi konselor dalam layanan bimbingan konseling virtual. Metode yang digunakan dalam penelitian ini adalah studi literatur dengan pendekatan deskriptif kualitatif. Sumber datanya berasal dari studi dokumen berupa buku dan penelitian terdahulu yang berasal dari berbagai referensi. Selanjutnya teknik analisis data yang digunakan adalah analisis deskriptif. Hasil penelitian ini menunjukkan bahwa konseling online berbentuk teknologi konseling virtual, yaitu, situs web, telepon atau ponsel, email, konferensi video, obrolan, pesan instan, komputer, dan jejaring sosial lainnya. Aspek etika yang harus dipatuhi konselor online adalah membangun hubungan baik di Internet, kerahasiaan saat melakukan konsultasi, aspek hukum telekomunikasi melalui Internet, dan perizinan. Oleh karena itu, konselor online perlu bersikap profesional dalam melakukan konseling virtual dengan mempertikan etika.
Article History

Received: 13-12-2021

Revised: 20-12-2021

Accepted: 27-12-2021

Published: 07-01-2022

Key Words:

Ethics, Online

Counselling, Online

Counsellor

\section{Sejarah Artikel}

Diterima: 13-12-2021

Direvisi: 20-12-2021

Disetujui: 27-12-2021

Diterbitkan: 07-01-2022

\section{Kata Kunci:}

Etika, Konseling Virtual, Konselor Online

How to Cite: Jannah, R., \& Marjo, H. (2022). Etika Profesi Konselor dalam Layanan Bimbingan Konseling Virtual. Jurnal Paedagogy, 9(1), 55-61. doi:https://doi.org/10.33394/jp.v9i1.4556

do)

https://doi.org/10.33394/ip.v9i1.4556

This is an open-access article under the CC-BY-SA License.

\section{Pendahuluan}

Perkembangan ilmu pengetahuan dan teknologi komunikasi telah membuat kemajuan dalam layanan konsultasi dalam menghadapi era 4.0. Konseling online pertama kali muncul pada dekade 1960 dan 1970 dengan perangkat lunak program Eliza dan Parry, awal perkembangan konseling online telah menjadi berbasis teks, dan sekitar 3 menit sekarang situs web pertama kali muncul hanya (Shaw, 2011). untuk memberikan konseling . Pada tahun 1999, ISMHO adalah, psikologi, psikiatri, pekerjaan sosial, keperawatan, terapi keluarga, mendirikan kelompok studi kasus klinis online yang terdiri dari ahli kesehatan mental di bidang konseling regional Online Clinical Case Study Group (CSG) (Dowling \& Rickwood, 2013).

Istilah nasihat online adalah dua kata yang berbeda. Dengan kata lain, "advice" berasal dari kata "advice" (bahasa Inggris) dan kata "online". Kedua kata tersebut dapat diartikan lebih lanjut sebagai berikut: Konselor/Klien Face on Face dengan tujuan 
menciptakan klien-mengambil tanggung jawab untuk diri sendiri pada berbagai kemungkinan masalah yang spesifik (Winkel \& Hastuti, 2011). Selanjutnya Haberstroh \& Duffey (2011) menjelaskan bahwa konseling online adalah klien dan penasihat yang menggunakan komunikasi melalui streaming video dan audio. Konsultan menggunakan komputer sebagai media komunikasi antara klien dan konsultan. Menurut (Koutsonika, 2011) konseling online dilakukan dengan menggunakan metode seperti live chat, telepon dan konseling video, di mana teknologi berkembang.

Dapat kita pahami dan simpulkan bahwa beberapa konseling online dari pendapat di atas merupakan upaya lain yang dapat dilakukan oleh konsultan secara virtual atau internet. Media di era industri sekarang ini semakin beragam, hadir dan mudah diakses dari smartphone, termasuk ponsel, internet, komputer bahkan media sosial. Semua media ini membantu konsultan dan klien memiliki akses antara konsultan dan klien di satu tempat di wajah atau tidak di wajah. Konseling online sebagai langkah menuju pelaksanaan bimbingan teknis dan jasa konsultasi mengharapkan etika dapat diterapkan pada nasihat dan bimbingan baik dalam pelaksanaan sebelum usia 4.0. Menjadi konsultan online profesional untuk layanan, tergantung pada kebutuhan dan kebutuhan era 4.0 inovasi.

Perkembangan konseling internet di Indonesia terutama sejak munculnya aplikasi jejaring sosial dalam kedua bentuk, seperti Zoom Meeting, Cloud, Google Meeting, Google Talk, Line, WhatsApp, Email, Facebook dan jenis aplikasi lainnya. dan pesan instan. Layanan ini disediakan oleh konsultan online untuk memberikan bantuan yang diperlukan dari klien ketika konseling tatap muka tidak memungkinkan. Dewasa ini para remaja, pelajar dan orang tua sering mengatakan demikian, karena jejaring media sosial telah menjadi bagian dari gaya hidup baru dan internet telah menjadi media komunikasi yang efektif dan efisien bagi masyarakat. masalah yang Anda hadapi dalam konteks Anda. Menyadari pentingnya konseling online, para konsultan secara konseptual memahami konseling lingkungan. Ecoconseling Indonesia secara khusus diperkenalkan ketika eco-conseling merupakan layanan konseling online (Ifdil \& Ardi, 2011).

Cyber counseling atau e-counseling adalah adalah salah satu model konseling virtual atau konseling yang dilakukan dengan bantuan koneksi internet, dan proses ini dapat memakan waktu jika konselor dan orang yang mencari nasihat tidak hadir secara fisik pada waktu yang sama. Melalui internet berupa website, email, Facebook, video conference, dan ide-ide inovatif lainnya (Pasmawati, 2016; Sari \& Herdi, 2021; Handika \& Herdi, 2021). Secara spesifik ada dua jenis layanan dalam konseling melalui internet, yaitu (Wibowo, 2016): (1) Non Interaktif dan (2) Interaktif Syncheonous maupun Interaktif Asyncronous. Oleh karena itu, konseling online merupakan salah satu alternatif strategi layanan konseling. Hal ini karena konseling layanan memiliki kebutuhan yang berkembang untuk saran dalam terang perkembangan terakhir. Dalam situasi ini, konsultan harus mampu menguasai prosedur, media virtual, dan etika yang digunakan dalam konseling online. Selain itu, artikel konseling online ini menjelaskan bagaimana memahami konsep layanan konseling online. Kedepannya, konsultan dalam pelaksanaan layanan eco-conseling dapat memberikan nasehat profesional melalui internet dalam melaksanakan nasehat online dengan memperhatikan etika.

\section{Metode Penelitian}

Penelitian ini menggunakan metode studi literatur dengan pendekatan deskriptif kualitatif. Hal ini sesuai dengan definisi penelitian kualitatif menurut (Moleong, 2013) yaitu prosedur penelitian yang menghasilkan data deskriptif berupa kata-kata tertulis atau lisan dari orang- 
orang dan perilaku yang diamati. Selain itu penelitian ini penelitian merupakan penelitian kajian pustaka. Kajian pustaka menurut (Fitrah \& Luthfiyah, 2017) adalah segala upaya yang dilakukan oleh peneliti untuk memperoleh dan menghimpun segala informasi tertulis yang relevan dengan masalah yang diteliti. Sumber data penelitian ini berasal dari studi dokumen berupa buku dan penelitian terdahulu yang berasal dari berbagai referensi yang dijadikan sumber data yang mendukung penelitian. Selanjutnya teknik analisis data yang digunakan adalah analisis deskriptif.

\section{Hasil Penelitian dan Pembahasan Konsep Etika}

Etika berasal dari bahasa Yunani ethos (kata tunggal) yang berarti: tempat tinggal, padang rumput, kandang, kebiasaan, adat, watak, sikap, cara berpikir. Bentuk jamaknya adalah ta, etha, yang berarti adat istiadat. Dalam hal ini, kata etika sama pengertianya dengan moral. Moral berasal dari kata latin: Mos (bentuk tunggal), atau mores (bentuk jamak) yang berarti adat istiadat, kebiasaan, kelakuan, watak, tabiat, akhlak, cara hidup (Nata, 2012). Menurut (Bertenz, 2017) etika memiliki dua arti. Praktis dan reflektif. Pada kenyataannya, etika berarti nilai-nilai dan norma-norma moral yang dipraktikkan atau tidak dipraktikkan ketika seharusnya. Etika praktis berarti moralitas dan hal yang sama dengan moralitas: apa yang harus dilakukan, apa yang tidak boleh dilakukan, apa yang harus dilakukan dengan benar, dan sebagainya. Etika sebagai refleksi adalah pemikiran moral.

Etika manusia dimanifestasikan dalam persepsi moral, termasuk keyakinan bahwa "itu benar, bukan sesuatu." Perasaan baru bahwa salah melakukan apa yang dia yakini salah menyimpang dari norma moral dan harga diri ketika dia pergi. Tindakan yang dia ambil harus menjadi tanggung jawabnya sendiri. Demikian pula sikapnya terhadap orang lain ketika karyanya bersifat merusak atau sebaliknya dipuji (Badroen, 2011)

\section{Proses Konseling Online}

Hasil penelitian teknologi virtual eco-conseling terus berkembang dalam bentuk konseling online berupa media: website, telepon/handphone, email, video conference, chat, instant messaging, komputer dan jaringan media sosial lainnya. untuk mengakses dari ponsel cerdas Anda. Etika yang harus dipatuhi konsultan online adalah membangun hubungan baik melalui internet, aspek kerahasiaan dalam memberikan nasihat, aspek hukum komunikasi melalui internet, dan perizinan. Oleh karena itu, konselor online perlu profesional dalam melakukan konseling online dengan bersikap etis. Adapun tahapan yang dilakukan dalam konseling online (Ifdil \& Ardi, 2011) bahwa proses konseling online terdiri dari tiga tahapan, sebagai berikut:

1) Tahap I (Persiapan)

Tahap persiapan meliputi aspek teknis penggunaan perangkat keras (tahap persiapan meliputi aspek teknis penggunaan perangkat keras untuk mendukung pelaksanaan konsultasi online. Misalnya perangkat komputer/laptop (software) yang mendukung pelaksanaan konsultasi online. Misalnya perangkat komputer/laptop yang dapat terkoneksi dengan Internet/Ethernet, headset, microphone, webcam, dll. Software, sebuah program yang digunakan untuk memberikan dukungan dan memberikan konselor pada keterampilan, prestasi akademik, penilaian etika dan hukum, kecukupan topik yang sedang dibahas, dan tata kelola. Anda dapat terhubung ke Internet / Ethernet, headset, mikrofon, webcam, dan lainnya. Perangkat lunak ini adalah program yang mendukung dan menggunakan akun dan alamat email. Keterampilan konsultan, latar belakang 
pendidikan, penilaian etika dan hukum, topik Kessuaische yang akan dibahas, dan tata kelola.

2) Tahap II (Proses Konseling)

Fase konseling online tidak jauh berbeda dengan fase proses tatap muka (face-to-face (FTF). Fase konsultasi online tidak jauh berbeda dengan fase proses konseling. Proses konseling terdiri dari lima fase: penyebaran, evaluasi, interpretasi, bimbingan, dan evaluasi, dan bersambungnamun dalam pelaksanaan "fleksibilitas berkelanjutan". Fase yang terhubung bersama dan dimodifikasi dengan benar terus membuka lebih banyak dari tahap awal hingga tahap akhir. Bahkan penggunaan teknikteknik secara umum dan khusus belum selesai secara langsung. Dalam sesi konseling online, terentasnya lebih menekankan pada masalah klien dibandingkan dengan metode pendekatan, teknik, dan/atau perawatan yang digunakan. Pada fase ini, pilihan teknik, pendekatan, atau pengobatan disesuaikan dengan masalah klien.

3) Tahap III (Pasca Konseling)

Tahap ketiga adalah konsultasi pasca-online. Fase ini merupakan lanjutan dari fase sebelumnya dan konsultasi pertama (1) berhasil setelah evaluasi dilakukan. Hal ini ditandai oleh keadaan klien dan oleh keadaan klien. KES (Effective Daily Life) adalah EDL) (2) Konseling berlanjut dalam sesi FtF tatap muka) (3) Konseling berlanjut pada konseling online berikutnya, (4) Klien adalah konselor lain atau yang dirujuk oleh ahli yang akan diperkenalkan kepada orang-orang.

\section{Etika Konseling Online}

Kode Etik untuk layanan konseling online sudah disusun standardnya oleh organisasi atau lembaga yang berwenang dibidang konseling diantaranya adalah (Council, 2011) tentang Penerapan Tekhnologi, Kode Etik dari American Mental Health Counselor Association (AMHCA, 2000) meliputi pedoman untuk konseling online internet bahwa isu-isu yang berkaitan dengan kerahasiaan alamat, klien dan identifikasi konselor, pembebasan klien, membangun hubungan konseling online, kompetensi, dan pertimbangan hukum. (Council, 2011) menyatakan bahwa psikolog etik yang melayani melalui transmisi elektronik menginformasikan klien/pasien tentang risiko privasi dan batasan kerahasiaan. Di sisi lain, di Indonesia, Ikatan Bimbingan Konseling Indonesia tidak mengeluarkan pedoman standarisasi layanan konseling melalui internet.

Secara khusus (NBC \& CCE) menjelaskan pedoman dan etika untuk layanan konsultasi melalui Internet. Secara umum, masalah etika tentang layanan konsultasi melalui Internet:

(1) Diskusikan informasi tentang kekuatan dan kelemahan layanan,

(2) Penggunaan dukungan teknis dalam operasi,

(3) Formulir akurasi layanan,

(4) Aplikasi Konsultasi Jarak Jauh Akses Komputer,

(5) Aspek Hukum dan Peraturan untuk Menggunakan Teknologi dalam Konsultasi,

(6) Teknologi Internal Masalah dan layanan teknis terkait bisnis lintas wilayah atau negara Masalah Hukum Jika Diberikan,

(7) Berbagai Konsultan Persetujuan bertemu tentang teknologi yang akan digunakan dan

(8) tentang penggunaan situs web dalam memberikan layanan konseling melalui Internet itu sendiri.

Seperti sebelumnya, delapan hal ini dapat dikategorikan menjadi tiga bagian utama. Kategori yang dilakukan oleh NBCC (Wibowo, 2016) yaitu mengenai (a) hubungan dalam konseling 
melalui internet (b) kerahasiaan dalam konseling melalui internet, dan (c) aspek hukum, lisensi dan sertifikasi. Berikut ini penjelasan dari masing-masing aspek tersebut:

1) Hubungan dalam konseling melalui internet

Dalam hal ini konsultan yang memberikan jasa melalui internet wajib menginformasikan berbagai situasi dan kondisi konsultasi yang perlu diketahui, dipahami, dan diterima oleh calon konsultan mengenai jasa konsultan melalui internet yang disediakan oleh konsultan tersebut (Nabilah, 2011).

2) Kerahasiaan dalam konseling melalui internet

Kerahasiaan dan keterbatasannya sangat penting bagi mereka yang mencurigai berbagai solusi. Secara umum, individu yang bekerja sebagai konsultan menjaga dan menjaga kerahasiaan dengan ketat. Hal ini juga diatur secara eksplisit oleh kode profesi konsultan. Oleh karena itu, sangat penting bagi konselor untuk menginformasikan konselor tentang aspek-aspek kerahasiaan, termasuk kerahasiaan layanan konseling di Internet.

3) Aspek hukum, lisensi dan sertifikasi

Kurangnya batas-batas geografis memberikan konselor dan konselor dari berbagai daerah dan bahkan negara kesempatan untuk berpartisipasi dalam proses pengobatan. Dari segi hukum, tentu saja hal ini menimbulkan persoalan mengenai bidang kegiatan dan perizinan konsultan. Oleh karena itu, jasa konsultasi melalui Internet memiliki etika yang diatur mengenai aspek hukum, persetujuan, dan sertifikasi. Untuk konsultan yang menyediakan layanan online melalui Internet

Etika yang perlu diketahui oleh konselor ketika melakukan konseling online adalah sebagai berikut (Glandding. T, 2012):

(1) Memahami potensi dan informasi dari mereka yang mencari nasihat.

(2) Kesempatan untuk mendukung dan setuju dengan mereka yang mencari nasihat selama konsultasi.

(3) Memahami identitas orang yang diberi konseling.

(4) Memahami risiko kerahasiaan komunikasi online.

(5) Menjaga komunikasi pribadi dan penyimpanan data (Gladding, 2012; Wibowo, 2016; Sutijono \& Ardika, 2018).

\section{Kategori Konseling Online}

Secara spesifik dalam pelaksanaan konseling online melalui media virtual internet terdapat dua jenis yaitu non interaktif dan interaktif synchronous maupun interaktif asynhronous (Mallen, 2015) .Sebagai berikut:

1) Non-interaktif: Pusat konseling yang menyediakan layanan non-interaktif adalah bentuk layanan informasi, dan jika digabungkan dengan konseling komprehensif, bentuk perawatan dasar (mendukung individu sebagai sumber daya dan menyediakan informasi diri). Konsentrasi dan swadaya pribadi).

2) Interaktif: Konseling interaktif adalah situs yang menyediakan terapi alternatif melalui Internet, di mana dialog antara orang yang meminta nasihat dan konselor bersifat langsung, sinkron, atau tidak sinkron. Di bawah ini adalah rincian jenis layanan yang ditawarkan oleh situs web yang menyediakan layanan dalam bentuk jenis interaktif. Ini tidak sinkron seperti email atau obrolan teks, jadi Anda tidak perlu duduk di depan komputer yang terhubung ke jaringan online. Ini biasanya berarti bahwa kerangka waktu di mana interaksi berlangsung diperpanjang. Butuh berjamjam, berhari-hari, dan bahkan berminggu-minggu untuk membalas pesan (Prasetya, 2017). 
(Corey, 2011) Kami menyimpulkan bahwa tidak cukup teknologi yang tersedia untuk semua atau semua pelanggan.

Untuk membenarkan secara etis teknologi yang digunakan untuk tujuan konsultasi, potensi manfaat harus lebih besar daripada potensi risiko bagi klien. Beberapa kelemahan konseling online adalah:

1) Kurangnya instruksi perilaku dan informasi nonverbal dapat menyebabkan. diagnosis yang tidak akurat dan pengobatan yang tidak efektif.

2) Kerahasiaan dan privasi tidak dapat dijamin.

3) Tugas terapis untuk memperingatkan atau melindungi orang lain terbatas.

4) Ide bunuh diri, kecemasan atau depresi ekstrem, atau klien yang terancam bahaya mungkin tidak mendapat perhatian segera yang sesuai.

5) Anonimitas memungkinkan anak-anak berpura-pura menjadi orang dewasa yang membutuhkan perawatan.

6) Sulit untuk menilai masalah metastasis dan kontratransferensi.

7) Sulit untuk memprediksi perkembangan aliansi terapeutik yang efektif dengan individu yang tidak ditemukan dalam konteks konseling tradisional.

8) Masalah psikologis yang kompleks dan jangka panjang hampir tidak dapat ditangani dengan baik.

\section{Kesimpulan}

Kesimpulan yang diperoleh dari studi literatur ini adalah konseling online berbentuk teknologi konseling virtual, yaitu, situs web, telepon atau ponsel, email, konferensi video, obrolan, pesan instan, komputer, dan jejaring sosial lainnya. Aspek etika yang harus dipatuhi konselor online adalah membangun hubungan baik di Internet, kerahasiaan saat melakukan konsultasi, aspek hukum telekomunikasi melalui Internet, dan perizinan. Oleh karena itu, konselor online perlu bersikap profesional dalam melakukan konseling virtual dengan mempertikan etika.

\section{Saran}

Etika konseling online dapat menjadi pertimbangan bagi konselor dalam melakukan proses konseling. Namun, itu tidak menghalangi prinsip dan metodologi yang penting untuk proses konsultasi yang tepat. Mahasiswa, dosen, konselor, dan mahasiswa perlu melihat kelemahan dan kekuatan teknologi untuk memahami dan menerapkan evolusi teknologi dalam konteks pendidikan, terutama dalam masalah etika konseling online. Sebagai manusia yang hidup dengan kemajuan berbagai zaman dan teknologi yang terus berkembang, menjadi tantangan bagi kita untuk selalu aktif merespon peluang yang diwujudkan dari sudut pandang teknologi. Sebaliknya, teknologi harus tersedia sebagai sarana dan media untuk meningkatkan kualitas pendidikan.

\section{Daftar Pustaka}

Badroen, F. (2011). Etika Bisnis dalam Islam. Jakarta: Kencana Perdana Media Group.

Bertenz, K. (2017). Etika. Jakarta: PT Gramedia Pustaka Utama.

Corey, G. \&. (2011). Issues and Ethics In The Helping Professions Eight Edition. USA: Brooks/Cole,Cengage Learning.

Council, A. C. A. G. (2011). ACA Code of Ethics. Journal of Counseling \& Development, 84(2), 235-254. https://doi.org/10.1002/j.1556-6678.2006.tb00401.x 
Dowling, M., \& Rickwood, D. (2013). Online counseling and therapy for mental health problems: A systematic review of individual synchronous interventions using chat. Journal of Technology in Human Services, 31(1), 1-21. https://doi.org/10.1080/15228835.2012.728508

Fitrah, M., \& Luthfiyah. (2017). Metodologi penelitian : penelitian kualitatif, tindakan kelas \& studi kasus. Sukabumi: Jejak.

Glandding. T, S. (2012). Profesi Yang Menyeluruh. Jakarta: PT. Indeks.

Haberstroh , S., \& Duffey, T. (2011). Face-to-face supervision of online counselors: Supervisor perspectives.

Handika, M., \& Herdi, H. (2021). Efektivitas Layanan E-Counseling dalam Membantu Permasalahan Siswa Selama Masa Pandemi Covid-19. Jurnal Paedagogy, 8(4), 506511. doi:https://doi.org/10.33394/jp.v8i4.3948

Ifdil, I., \& Ardi, Z. (2011). Konseling online sebagai salah satu bentuk pelayanan ekonseling. Jurnal Konseling dan Pendidikan, 1(1), 15-22.

Koutsonika, H. (2011). E-Counseling: the new modality. Online Career Counseling-a challenging opportunity for greek tertiary education.

Mallen, M. J. (2015). Online counseling: Reviewing the literature from a counseling psychology framework. The Counseling Psychologist, 33(6), 819-871.

Moleong, L. J. (2013). Metode Penelitian Kualitatif. Bandung: Remaja Rosdakarya.

Nabilah. (2011). Pengembangan Media Layanan Konseling Internet di Perguruan Tinggi (Studi keterbacaan Media Layanan Konseling Internet di Universitas Negeri Jakarta).

Nata, A. (2012). Akhlak Tasawuf dan Karakter Mulia. Jakarta: Raja Grafindo.

NBC, N., \& CCE, C. (t.thn.). The Practice of Internet Counseling.

Pasmawati, H. (2016). Cyber Counseling Sebagai Metode Pengembangan Layanan Konseling Di Era Global. Jurnal Ilmiah Syi'ar, 16(2), 34-54.

Prasetya, A. F. (2017). Model Cybercounseling: Telaah Konseling Individu Online ChatAsynchronous Berbasis Aplikasi Android. n Prosiding Seminar Bimbingan dan Konseling (Vol. 1, No. 1, pp. 31-38).

Sari, M., \& Herdi, H. (2021). Cyber Counseling : Solusi Konseling di Masa Pandemi. Jurnal Paedagogy, 8(4), 579-585. doi:https://doi.org/10.33394/jp.v8i4.3949

Shaw, H. E. (2011). Critical ethical issues in online counseling: Assessing current practices with an ethical intent checklist. Journal of Counseling \& Development, 84(1), 4153.

Wibowo. (2016). Manajemen kinerja. Rajawali Pers.

Winkel, S. W., \& Hastuti, S. (2011). Bimbingan dan konseling di institusi pendidikan. Jakarta: Gramedia. 